\title{
A randomised, single-blind, placebo-controlled, dose-finding safety and tolerability study of the anti-CD3 monoclonal antibody otelixizumab in new-onset type 1 diabetes
}

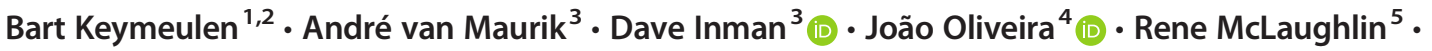

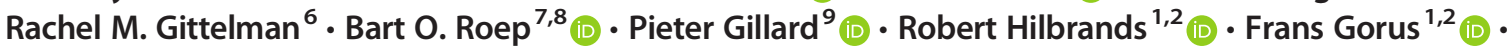 \\ Chantal Mathieu ${ }^{9}$ (D) Ursule Van de Velde ${ }^{1,2} \cdot$ Nicolas Wisniacki $^{3}$ (D) $\cdot$ Antonella Napolitano $^{3}$
}

Received: 14 May 2020 / Accepted: 9 September 2020 / Published online: 4 November 2020

(C) The Author(s) 2020

\begin{abstract}

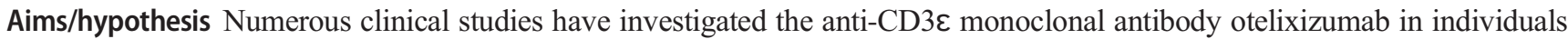
with type 1 diabetes, but limited progress has been made in identifying the optimal clinical dose with acceptable tolerability and safety. The aim of this study was to evaluate the association between dose-response, safety and tolerability, beta cell function preservation and the immunological effects of otelixizumab in new-onset type 1 diabetes.

Methods In this randomised, single-blind, placebo-controlled, 24 month study, conducted in five centres in Belgium via the Belgian Diabetes Registry, participants (16-27 years old, $<32$ days from diagnosis of type 1 diabetes) were scheduled to receive placebo or otelixizumab in one of four dose cohorts (cumulative i.v. dose 9, 18, 27 or $36 \mathrm{mg}$ over 6 days; planned $n=40$ ). Randomisation to treatment was by a central computer system; only participants and bedside study personnel were blinded to study treatment. The co-primary endpoints were the incidence of adverse events, the rate of Epstein-Barr virus (EBV) reactivation, and laboratory measures and vital signs. A mixed-meal tolerance test was used to assess beta cell function; exploratory biomarkers were used to measure $\mathrm{T}$ cell responses.

Results Thirty participants were randomised/28 were analysed (placebo, $n=6 / 5$; otelixizumab $9 \mathrm{mg}, n=9 / 8$; otelixizumab $18 \mathrm{mg}, n=8 / 8$; otelixizumab $27 \mathrm{mg}, n=7 / 7$; otelixizumab $36 \mathrm{mg}, n=0$ ). Dosing was stopped at otelixizumab $27 \mathrm{mg}$ as the predefined EBV reactivation stopping criteria were met. Adverse event frequency and severity were dose dependent; all participants on otelixizumab experienced at least one adverse event related to cytokine release syndrome during the dosing period. EBV reactivation (otelixizumab $9 \mathrm{mg}, n=2 / 9 ; 18 \mathrm{mg}, n=4 / 8: 27 \mathrm{mg}, n=5 / 7$ ) and clinical manifestations (otelixizumab $9 \mathrm{mg}$, $n=0 / 9 ; 18 \mathrm{mg}, n=1 / 8 ; 27 \mathrm{mg}, n=3 / 7$ ) were rapid, dose dependent and transient, and were associated with increased productive $\mathrm{T}$ cell clonality that diminished over time. Change from baseline mixed-meal tolerance test C-peptide weighted mean $\mathrm{AUC}_{0-120}$ min following otelixizumab $9 \mathrm{mg}$ was above baseline for up to 18 months (difference from placebo 0.39 [95\% CI 0.06, 0.72]; $p=$ 0.023); no beta cell function preservation was observed at otelixizumab 18 and $27 \mathrm{mg}$.
\end{abstract}

Supplementary Information The online version of this article (https:// doi.org/10.1007/s00125-020-05317-y) contains peer-reviewed but unedited supplementary material, which is available to authorised users.

Bart Keymeulen

bart.keymeulen@vub.be

Antonella Napolitano

Antonella.2.napolitano@gsk.com

1 Academic Hospital and Diabetes Research Center, Vrije Universiteit Brussel, Brussels, Belgium

2 Belgian Diabetes Registry, Brussels, Belgium

3 GlaxoSmithKline Medicines Research Centre, Stevenage, UK

4 GlaxoSmithKline, Global Clinical Operations, Cambridge, UK
5 Department of Immunology and Blood Transfusion, Leiden University Medical Center, Leiden, the Netherlands

6 Adaptive Biotechnologies, Seattle, WA, USA

7 Department of Internal Medicine, Leiden University Medical Center, Leiden, the Netherlands

8 Department of Diabetes Immunology, Diabetes \& Metabolism Research Institute, Beckman Research Institute at the City of Hope, Duarte, CA, USA

9 Department of Endocrinology, University Hospitals Leuven-KUL, Leuven, Belgium 


\section{Research in context}

\section{What is already known about this subject?}

- The anti-CD3 monoclonal antibody otelixizumab has been shown to preserve $\mathrm{C}$-peptide secretion in individuals with new-onset type 1 diabetes, but at a dose that causes cytokine release syndrome and induces Epstein-Barr virus (EBV) reactivation

What is the key question?

- What cumulative dose of otelixizumab is well tolerated, while maintaining the potential for beta cell function preservation, in individuals with recent-onset type 1 diabetes?

What are the new findings?

- In this study in individuals with new-onset type 1 diabetes, a cumulative dose of $9 \mathrm{mg}$ otelixizumab preserved beta cell function over 18 months. These results may be related to a higher baseline beta cell residual function in this group, indicating that anti-CD3 monoclonal antibody therapy might be more effective in the prevention setting when overt hyperglycaemia is not yet apparent

- Based on stopping criteria around cytokine release syndrome and clinical EBV reactivation, otelixizumab $18 \mathrm{mg}$ was the maximum tolerated dose, whereas no participants who received otelixizumab $9 \mathrm{mg}$ developed clinical signs of EBV reactivation

\section{How might this impact on clinical practice in the foreseeable future?}

- Our data show that otelixizumab can temporarily compromise immunocompetence in a dose-dependent manner. This phenomenon is transient, as evidenced by a rapid emergence of EBV-specific T cells preceding long-term control over EBV reactivation. This observation may indicate the need to explore an increased safety margin when implementing the use of anti-CD3 monoclonal antibody therapy in a prevention setting

Conclusions/interpretation A metabolic response was observed with otelixizumab $9 \mathrm{mg}$, while doses higher than 18 mg increased the risk of unwanted clinical EBV reactivation. Although otelixizumab can temporarily compromise immunocompetence, allowing EBV to reactivate, the effect is dose dependent and transient, as evidenced by a rapid emergence of EBV-specific T cells preceding long-term control over EBV reactivation.

Trial registration ClinicalTrials.gov NCT02000817.

Funding The study was funded by GlaxoSmithKline.

Keywords Anti-CD3 monoclonal antibody $\cdot$ Autoreactive T cell $\cdot$ Epstein-Barr virus reactivation · Islet autoimmunity $\cdot$ Type 1 diabetes

$\begin{array}{ll}\text { Abbreviations } \\ \text { AE } & \text { Adverse event } \\ \text { CRS } & \text { Cytokine release syndrome } \\ \text { EBV } & \text { Epstein-Barr virus } \\ \text { MMTT } & \text { Mixed-meal tolerance test } \\ \text { PBMC } & \text { Peripheral blood mononuclear cell } \\ \text { SAE } & \text { Serious adverse event } \\ \text { TCR } & \text { T cell receptor }\end{array}$

\section{Introduction}

Type 1 diabetes is a chronic, progressive disease characterised by $\mathrm{T}$ cell-mediated autoimmune destruction of insulin- producing pancreatic beta cells $[1,2]$. The cytotoxic $\mathrm{T}$ cell infiltrate in inflamed islets is dominated by $\mathrm{CD}^{+}$lymphocytes, but may also contain $\mathrm{CD}^{+}$lymphocytes, B lymphocytes and macrophages [3]. Clinical symptoms usually develop when most functional beta cell mass has been lost [4], by which time individuals with type 1 diabetes depend on exogenous insulin and lifestyle management as the mainstays of treatment [5]. Even with intensive insulin therapy, individuals with type 1 diabetes are at risk of acute complications such as hypoglycaemia and ketoacidosis, and of long-term microvascular and macrovascular complications [6, 7].

Therapies targeting $\mathrm{T}$ cells have been an area of much interest in new-onset type 1 diabetes. In particular, monoclonal antibodies against CD3 can change the natural course of type 1 diabetes, leading to a longer preservation of beta cell function [8]. High cumulative doses of humanised anti-CD3 
antibodies have been shown to maintain baseline plasma Cpeptide levels over at least 18 months in a subgroup of individuals with stage 3 , recent-onset type 1 diabetes [9-13]; however, clinically relevant metabolic effects have to be weighed against side effects during and after treatment, as anti-CD3 antibody administration can cause reactivation of Epstein-Barr virus (EBV) and induce a local (if subcutaneously administered [14]) or systemic (if intravenously administered $[9,10])$ cytokine release response.

Otelixizumab is a humanised, Fc-modified, non-mitogenic, anti-CD3 monoclonal antibody with limited $\mathrm{Fc}$ receptor binding $[9,15]$. A Phase II, placebo-controlled trial of otelixizumab (total dose of $48 \mathrm{mg}$ administered over 6 days) demonstrated preserved residual beta cell function for at least 18 months in participants with recent-onset type 1 diabetes; however, $75 \%$ of those treated with otelixizumab developed symptoms consistent with acute mononucleosis, and all participants who received otelixizumab had transient adverse events (AEs) associated with cytokine release syndrome (CRS) [9]. In the Phase III Durable Response Therapy Evaluation for Early or New-Onset Type 1 Diabetes studies, which evaluated a total dose of otelixizumab of $3.1 \mathrm{mg}$ (administered over 8 days), treatment was well tolerated but was not efficacious in terms of beta cell preservation [16, 17], highlighting the need to establish an optimal otelixizumab dose in terms of both safety and efficacy.

The primary aim of this Phase I/II study was to identify a dosage regimen of intravenously administered, escalating doses of otelixizumab with an acceptable safety and tolerability profile, which is considered a necessary first step to determining the therapeutic index of otelixizumab. In addition, the C-peptide rate of decline in participants with new-onset type 1 diabetes and detailed immunological mechanisms were investigated. To this end, partially exhausted $\mathrm{CD}^{+}$memory $\mathrm{T}$ cells were monitored to evaluate any association with metabolic response in halting or slowing $\beta$-cell destruction in this population. Furthermore, changes in the $\mathrm{T}$ cell repertoire and $\mathrm{EBV}$-reactive $\mathrm{CD} 8^{+} \mathrm{T}$ cells were investigated to gain insights into immunological responses following EBV reactivation. The pharmacological findings from this study have been reported previously, and showed that serum otelixizumab concentrations increased with ascending doses (9, 18 and $27 \mathrm{mg}$ ) and $\mathrm{CD} 3 \varepsilon$ target engagement was rapidly achieved with all doses, with the two highest doses achieving approximately $90 \%$ target engagement and consequential CD3E/ $\mathrm{T}$ cell receptor (TCR) downmodulation by day 6 [18].

\section{Methods}

\section{Study design and study population}

Full details of the study design, study population and ethics approval have been reported elsewhere [18] and are described in brief here. This study was a randomised, single-blind, placebo-controlled, dose-ascending study, conducted in five centres in Belgium via the Belgian Diabetes Registry between March 2014 and September 2018 (ClinicalTrials.gov NCT02000817). Otelixizumab was planned to be dosed by daily i.v. infusions over 6 days in four dose cohorts at a total dose of $9 \mathrm{mg}$ (cohort 1), $18 \mathrm{mg}$ (cohort 2), $27 \mathrm{mg}$ (cohort 3) or $36 \mathrm{mg}$ (cohort 4). Participants were randomised to treatment by a secure, central computer system using a randomisation schedule generated by GlaxoSmithKline Clinical Statistics, UK. Only participants and bedside study personnel were blinded to study treatment. In addition, the sponsor team members were unblinded to study treatment. Participants were dosed in hospital for the first 3 days (slower rate of infusion [17]) and as outpatients on days 4-6; the otelixizumab dose was divided equally over the 6 days of dosing. Full details of the dosing regimens are shown in electronic supplementary material (ESM) Table 1. Following the last day of dosing, participants were followed up as outpatients at days 14 and 21, weeks 4 and 6, and months 2, 3, 6, 9, 12, 18 and 24. Prophylaxis for CRS included non-steroidal antiinflammatory drugs and non-sedating oral antihistamines (cetirizine) and was given to all participants $1-2 \mathrm{~h}$ prior to and during dosing with otelixizumab. In addition, the antiemetic ondansetron, a $5 \mathrm{HT}_{3}$-receptor antagonist, was permitted for those receiving otelixizumab $18 \mathrm{mg}$ or more (as per protocol amendment).

Individuals were eligible for the trial if they were 1627 years old, less than 32 days from a diagnosis of type 1a (autoimmune) diabetes and positive for at least one autoantibody associated with type 1 diabetes, and had evidence of residual functioning beta cells as measured by a mixed-meal stimulated C-peptide peak level of $\geq 0.2 \mathrm{nmol} / \mathrm{l}$. Participants who were positive for EBV capsid antibody IgM in the absence of positive EBV nuclear antigen IgG, had an EBV viral load of $>10,000$ copies $/ 10^{6}$ peripheral blood mononuclear cells (PBMCs) or who were IgG negative for EBV were excluded.

Dose escalation (i.e. initiation of treatment in next participant cohort) was decided upon pre-established stopping criteria around in-stream, real-time data review of CRS variables based on the maximum number of participants experiencing CRS symptoms of grade 3 or worse (three out of eight participants on active treatment) (ESM Table 2) and the number of participants showing clinical and virological EBV reactivation (Table 1).

The study was carried out with the approval of the ethics committees of all participating hospitals, the Belgian Diabetes Registry and the Belgian national regulatory agency. Written consent was obtained from all participants older than 18 years, and from participants aged 16-18 years and their parents/ guardians. 
Table 1 Protocol-defined doseescalation EBV reactivation stopping criteria

\begin{tabular}{ll}
\hline EBV reactivation & Criteria $^{\mathrm{a}}$ \\
\hline $\begin{array}{l}\text { Clinical symptoms of } \\
\text { mononucleosis }\end{array}$ & Fever, fatigue, malaise, myalgia, pharyngodynia, lymphadenopathy \\
Change in viral load & EBV by PCR $>10,000$ copies $/ 10^{6}$ PBMCs \\
Change in serology & Emergence of IgM for EBV on otherwise EBV IgG-positive participants
\end{tabular}

${ }^{a}$ Stopping criteria: If three or more of eight participants on active treatment within a cohort developed symptoms of clinical EBV reactivation, otelixizumab dosing was stopped and no further dosing was carried out on any other participants; participants who had been dosed were followed up as per protocol

\section{Safety}

The primary study objective was to assess the safety and tolerability of otelixizumab over 24 months. Safety assessments, including clinical laboratory tests (haematology, clinical chemistry and serology), vital signs, ECGs and physical examinations were conducted every day during the dosing period and at regular intervals during the 24 month followup. Specific liver chemistry stopping criteria were followed as detailed in the ESM Methods. Liver function variables were assayed by a local laboratory as part of routine clinical chemistry laboratory testing. AEs were monitored throughout the study.

EBV viral load detection Blood samples for EBV viral load detection were collected at predose baseline, predose on day 6 of dosing, at day 21, and at months 2, 3,6 and 24. EBV load was quantified per $10^{6}$ PBMCs. During the life-phase of the study, measurement of EBV DNA load was performed on DNA extracted from PBMCs using a quantitative real-time PCR assay (Abbott RealTime EBV assay; Abbott Molecular, USA). The assay was validated and performed by $\mathrm{Q}^{2}$ Solutions (UK) [19].

\section{Efficacy}

Metabolic endpoints A mixed-meal tolerance test (MMTT) was conducted at months $3,6,12,18$ and 24 to determine the blood levels of C-peptide and glucose in response to a standardised amount of Ensure powder (Abbott, the Netherlands). Blood samples were collected at $10 \mathrm{~min}$ before, immediately before and 15, 30, 60, 90 and 120 min after meal consumption. The MMTT C-peptide AUC from time 0 to $120 \mathrm{~min}\left(\mathrm{AUC}_{0-120} \mathrm{~min}\right)$ was calculated using the trapezoidal rule, normalised for time interval. A metabolic responder was defined as a participant with a change in C-peptide MMTT weighted mean AUC at 24 months of $<40 \%$ from baseline [20].

A hyperglycaemic clamp procedure [9] was performed at baseline, and after 6 and 24 months. Plasma C-peptide and glucose levels were measured during the procedure at: 150 , 165 and 180 min during the euglycaemic low phase and at 0 , $60,90,120$ and 140 min during the hyperglycaemic high phase. C-peptide AUC from time 60 to 140 min during the hyperglycaemic high phase was calculated and expressed as value per min for each period. The insulin sensitivity index was calculated [21]. The MMTT and hyperglycaemic clamp tests were separated by at least 4 days.

Mean daily insulin use (IU [ $\mathrm{kg}$ body weight $]^{-1}$ day $^{-1}$ ) was calculated over the 7 days prebaseline, on days 14 and 21, at weeks 4 and 6, and at months 2, 3, 6, 9, 12, 18 and 24 . Measurement of $\mathrm{HbA}_{1 \mathrm{c}}$ was performed at predose baseline and months 6 and 24 [22].

\section{Immunogenicity}

Blood samples to assess serum anti-drug antibody levels were collected at baseline and months 3 and 6. Samples were analysed using a validated immuno-electrochemiluminescence assay (Drug Metabolism and Pharmacokinetics, GlaxoSmithKline, USA).

\section{Exploratory biomarkers}

Flow cytometry Lymphocyte subsets were phenotyped and quantified by flow cytometry, as detailed in ESM Methods.

TCR immunosequencing $\mathrm{T}$ cell clonality was determined using the TCRB immunoSEQ Assay (Adaptive Biotechnologies, USA), as detailed in ESM Methods.

\section{Statistical analysis}

Sample sizes were based on feasibility, to primarily allow characterisation of the safety and tolerability of ascending doses of otelixizumab in individuals with type 1 diabetes. A total of 40 participants were planned for the study, comprising eight participants randomised to otelixizumab and two to placebo in each cohort. All safety data are summarised descriptively. Change from baseline in C-peptide and glucose levels following the MMTT and hyperglycaemic clamp tests were analysed using a mixed-model repeated-measures analysis adjusted for treatment, visit and baseline. Non-parametric statistical tests were used to compare the level of productive clonality between the placebo and active-treatment groups (Mann-Whitney $U$ test) and productive clonality over time in each treatment group (Wilcoxon signed-rank test). 


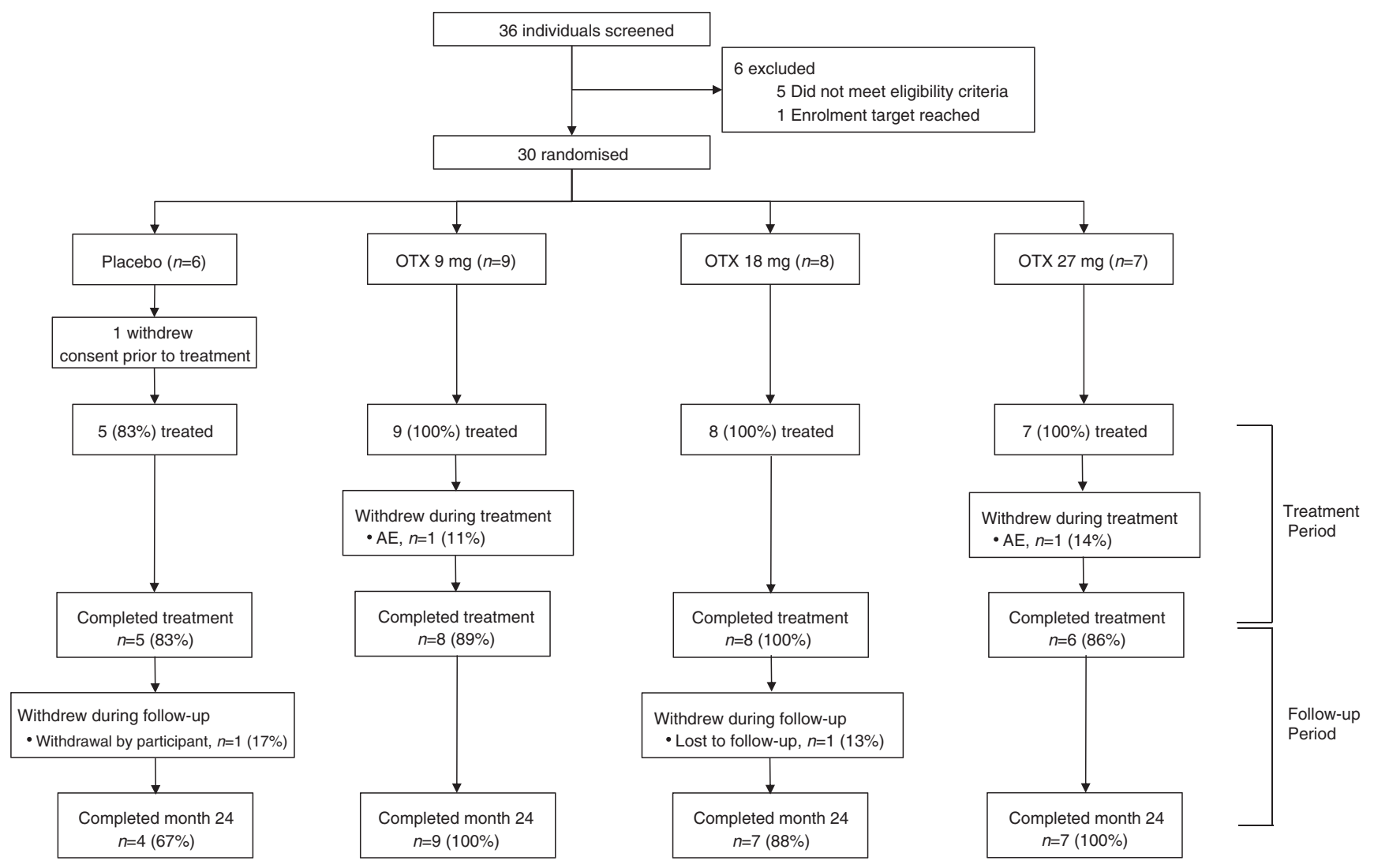

Fig. 1 Participant flow diagram. OTX, otelixizumab

\section{Results}

\section{Participant characteristics}

Of 36 individuals screened, 30 were randomised to treatment: six with placebo (two in each of cohorts 1,2 and 3), nine with otelixizumab $9 \mathrm{mg}$ (cohort 1), eight with otelixizumab $18 \mathrm{mg}$ (cohort 2) and seven with otelixizumab $27 \mathrm{mg}$ (cohort 3) (Fig. 1). No participants were randomised to receive otelixizumab $36 \mathrm{mg}$ (cohort 4 ) as the predefined stopping criteria on EBV reactivation were met at the $27 \mathrm{mg}$ dose. Two participants withdrew from otelixizumab treatment: one in the $9 \mathrm{mg}$ group because of an $\mathrm{AE}$ on day 2 of treatment and one in the $27 \mathrm{mg}$ group because of a serious AE (SAE) on day 5 of treatment. Both participants remained in the trial and completed a minimum of 24 months of safety follow-up. Three participants withdrew from the study or were lost to follow-up: two participants in the placebo group withdrew themselves (one prior to receiving any treatment and one during follow-up); and one participant in the $18 \mathrm{mg}$ group was lost to follow-up. All data collected from participants who withdrew from the treatment or study were included in the relevant analyses up to the point of study withdrawal.

Baseline characteristics were generally similar across the groups (Table 2).

\section{Safety}

Overall, the frequency and severity of AEs were dose dependent, with a higher frequency in participants receiving otelixizumab (vs placebo) around the time of dosing (Table 3). During the dosing period, drug-related grade 2 and 3 AEs occurred with all otelixizumab doses and in similar percentages of participants (ESM Table 3). The most common AEs reported during the dosing period were headache, nausea, vomiting and rash (Table 3). Headache occurred in all participants on active treatment. Nausea and vomiting occurred less frequently in the otelixizumab $9 \mathrm{mg}$ group (56\% and $44 \%$, respectively) compared with the $18 \mathrm{mg}$ group (88\% and $75 \%$, respectively) and $27 \mathrm{mg}$ group (both 100\%). Rash occurred in active-treatment groups only, but not in a dosedependent manner (otelixizumab $9 \mathrm{mg}, 44 \% ; 18 \mathrm{mg}, 63 \%$; $27 \mathrm{mg}, 43 \%$ ). One individual in the $9 \mathrm{mg}$ group on active treatment stopped participation before the end of dosing because of CRS-related AEs (which did not meet the protocol stopping criteria), and one participant in the $27 \mathrm{mg}$ group on active treatment was diagnosed with cytomegalovirus primoinfection on day 5 of the dosing period, reported as a drugrelated SAE. This participant was not given the last dose of otelixizumab (day 6) and was immediately treated as per standard of care (ganciclovir). The infection and all symptoms resolved within 13 days. This SAE was reported as a 
Table 2 Baseline characteristics

\begin{tabular}{|c|c|c|c|c|}
\hline Characteristic & Placebo $(n=5)$ & OTX 9 mg $(n=9)$ & OTX $18 \mathrm{mg}(n=8)$ & OTX $27 \mathrm{mg}(n=7)$ \\
\hline Age, years & $24.8 \pm 4.44$ & $22.4 \pm 2.13$ & $20.5 \pm 4.31$ & $22.1 \pm 3.98$ \\
\hline Age group $16-17$ years, $n$ & 1 & 0 & 3 & 1 \\
\hline Age group $\geq 18$ years, $n$ & 4 & 9 & 5 & 6 \\
\hline Male/female, $n$ & $3 / 2$ & $6 / 3$ & $5 / 3$ & $5 / 2$ \\
\hline BMI, $\mathrm{kg} / \mathrm{m}^{2}$ & $22.7 \pm 2.12$ & $23.1 \pm 4.28$ & $21.4 \pm 2.01$ & $21.4 \pm 2.21$ \\
\hline Height, cm & $169.2 \pm 8.66$ & $177.0 \pm 8.95$ & $172.8 \pm 9.73$ & $174.4 \pm 7.50$ \\
\hline Weight, kg & $65.2 \pm 10.61$ & $72.8 \pm 16.12$ & $64.2 \pm 9.55$ & $65.3 \pm 8.71$ \\
\hline \multicolumn{5}{|l|}{ Race } \\
\hline White & $5(100)$ & $9(100)$ & $8(100)$ & $7(100)$ \\
\hline \multicolumn{5}{|l|}{ Autoantibody prevalence at screening } \\
\hline Multiple autoantibody positive & $5(100)$ & $9(100)$ & $7(88)$ & $7(100)$ \\
\hline GADA positive & $5(100)$ & $6(67)$ & $8(100)$ & $7(100)$ \\
\hline IA2A positive & $4(80)$ & $7(78)$ & $7(88)$ & $6(86)$ \\
\hline Znt8A positive & $3(60)$ & $8(89)$ & $2(25)$ & $5(71)$ \\
\hline IAA positive & $1(20)$ & $3(33)$ & $2(25)$ & $1(14)$ \\
\hline $\mathrm{HbA}_{1 \mathrm{c}}, \%$ & $8.1 \pm 1.74$ & $7.1 \pm 1.53$ & $6.8 \pm 1.48$ & $6.8 \pm 1.80$ \\
\hline $\mathrm{HbA}_{1 \mathrm{c}}, \mathrm{mmol} / \mathrm{mol}$ & $80.6 \pm 17.40$ & $70.8 \pm 15.27$ & $67.6 \pm 14.79$ & $68.1 \pm 17.98$ \\
\hline Insulin use in the 7 days before baseline, $\mathrm{IU} \mathrm{kg}^{-1}$ day $^{-1}$ & $0.46 \pm 0.112$ & $0.40 \pm 0.210$ & $0.37 \pm 0.215$ & $0.40 \pm 0.235$ \\
\hline Insulin sensitivity index $\left(\mu \mathrm{mol} \mathrm{kg}{ }^{-1} \min ^{-1}(\mathrm{pmol} / \mathrm{l})^{-1}\right)$ & $0.0018 \pm 0.00095$ & $0.0015 \pm 0.00076$ & $0.0018 \pm 0.00087$ & $0.0015 \pm 0.00114$ \\
\hline
\end{tabular}

Data are means $\pm \mathrm{SD}$ or $n(\%)$, unless otherwise stated

Baseline refers to screening or day 1 prior to randomisation

GADA, GAD antibody; IAA, insulin autoantibody; IA2A, insulinoma-associated protein 2 autoantibody; OTX, otelixizumab; Znt8A, zinc transporter 8 autoantibody

suspected unexpected serious adverse reaction. The incidence of other SAEs during the 2 year follow-up was low (placebo, $n=1$; otelixizumab $9 \mathrm{mg}, n=2$; otelixizumab $18 \mathrm{mg}, n=1$ ). None of these SAEs was assessed as drug-related.

During the postdose to week 6 period, the most commonly reported $\mathrm{AE}$ assessed as drug-related (excluding those related to the underlying disease) was rash, which was observed to be dose related (Table 3 ). In this period, drug-related symptoms of grade 2 or higher also appeared to be dose dependent; no participants in the otelixizumab $9 \mathrm{mg}$ group had postdose drug-related AEs of grade 2 or worse (ESM Table 3). Beyond Week 6, no patterns were observed in AEs related to study treatment, and there were no differences between active treatment and placebo.

At all doses, some transient increased liver function test results were observed during the dosing period, but none reached the protocol-defined stopping criteria. No significant abnormal clinical chemistry or haematology results were reported, apart from lymphocytopenia observed after day 1 , which resolved at day 14 postdosing. No clinically significant changes in vital signs or ECGs were noted at any time point.

EBV reactivation A progressively higher number of participants had transient abnormally high EBV PCR levels with ascending otelixizumab dose, with peak levels measured at day 21 (Fig. 2). EBV reactivation and associated clinical signs were rapid, dose dependent and transient. EBV reactivation occurred in: otelixizumab ( $9 \mathrm{mg}), n=2 / 9 ;(18 \mathrm{mg}), n=4 / 8$ : (27 mg), $n=5 / 7$ (Fig. 2). In the otelixizumab 18 and $27 \mathrm{mg}$ groups, respectively, one out of eight and three out of seven participants had clinical signs of EBV reactivation (Fig. 2). No participants in the otelixizumab $9 \mathrm{mg}$ group showed any clinical signs of EBV reactivation, but there was evidence of an increased EBV viral load in this group (Fig. 2).

\section{Efficacy}

Metabolic endpoints Following MMTT, the weighted mean $\mathrm{AUC}_{0-120 \mathrm{~min}} \mathrm{C}$-peptide $(\mathrm{nmol} / \mathrm{l} \times \mathrm{min})$ increased above baseline at 3 months and then progressively decreased over time in all groups (Fig. 3). In the otelixizumab $9 \mathrm{mg}$ group, the change from baseline at month 18 was statistically significant compared with placebo (least-squares mean difference from placebo 0.39 [95\% CI 0.06, 0.72], $p=0.023$ ). In the other otelixizumab groups, mean AUC C-peptide was lower at month 18 than before treatment. Baseline mean C-peptide was numerically higher in the otelixizumab $9 \mathrm{mg}$ group than in the other groups (baseline C-peptide weighted mean $\pm \mathrm{SD}$ $\mathrm{AUC}_{0-120} \min (\mathrm{nmol} / 1 \times \min )$ : placebo, $0.55 \pm 0.25$; 
Table 3 Summary of AEs

\begin{tabular}{|c|c|c|c|c|}
\hline Type of AE & Placebo $(n=5)$ & OTX $9 \mathrm{mg}(n=9)$ & OTX $18 \mathrm{mg}(n=8)$ & OTX $27 \mathrm{mg}(n=7)$ \\
\hline \multicolumn{5}{|l|}{ During dosing } \\
\hline AEs related to study treatment & $4(80)$ & $9(100)$ & $8(100)$ & $7(100)$ \\
\hline AEs leading to permanent discontinuation of study treatment & 0 & $1(11)$ & 0 & $1(14)$ \\
\hline SAEs related to study treatment & 0 & 0 & 0 & $1(14)$ \\
\hline \multicolumn{5}{|l|}{ Most frequent AEs related to study treatment ${ }^{\mathrm{a}}$} \\
\hline Headache & $1(20)$ & $9(100)$ & $8(100)$ & $7(100)$ \\
\hline Nausea & $1(20)$ & $5(56)$ & $7(88)$ & $7(100)$ \\
\hline Vomiting & 0 & $4(44)$ & $6(75)$ & $7(100)$ \\
\hline Rash & 0 & $4(44)$ & $5(63)$ & $3(43)$ \\
\hline \multicolumn{5}{|l|}{ Postdose to week 6} \\
\hline AEs related to study treatment & $3(60)$ & $7(78)$ & $7(88)$ & $7(100)$ \\
\hline \multicolumn{5}{|l|}{ Most frequent AEs related to study treatment ${ }^{\mathrm{a}}$} \\
\hline Rash & 0 & 0 & $3(38)$ & $3(43)$ \\
\hline Skin exfoliation & 0 & $3(33)$ & 0 & 0 \\
\hline Lymphadenopathy & 0 & 0 & $1(13)$ & $3(43)$ \\
\hline \multicolumn{5}{|l|}{ Postdose week 6-month 24} \\
\hline AEs related to study treatment ${ }^{\mathrm{b}}$ & $5(100)$ & $8(89)$ & $5(63)$ & $5(71)$ \\
\hline
\end{tabular}

Data are $n(\%)$

${ }^{a}$ Excludes AEs related to the underlying condition (i.e. hypoglycaemia and hyperglycaemia)

${ }^{\mathrm{b}}$ No events (other than hypoglycaemia and hyperglycaemia) occurred in more than one participant OTX, otelixizumab

otelixizumab $9 \mathrm{mg}, 0.80 \pm 0.29 ; 18 \mathrm{mg}, 0.67 \pm 0.35 ; 27 \mathrm{mg}$, $0.60 \pm 0.24)$. The number of participants meeting the definition of being a C-peptide responder at month 24 was: placebo, $1(20 \%)$; otelixizumab $9 \mathrm{mg}, 6(67 \%) ; 18 \mathrm{mg}, 2$ (25\%); $27 \mathrm{mg}$, $4(57 \%)$.

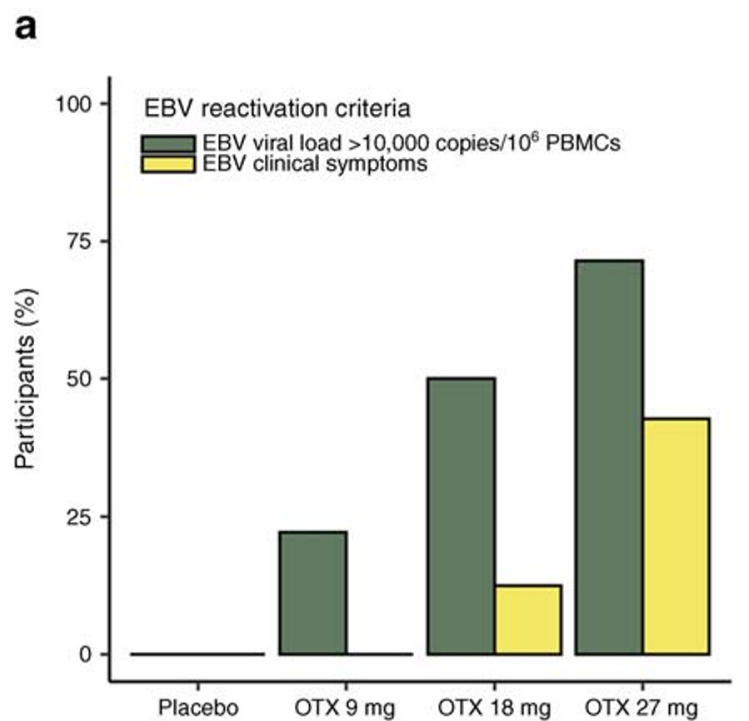

Mean AUC glucose $(\mathrm{mmol} / 1 \times \min )$ during MMTT was below baseline only in the otelixizumab $9 \mathrm{mg}$ group, at months 3, 6 and 24 (but not month 12 or 18) and was numerically lower than placebo at all postbaseline timepoints (ESM Fig. 1). In the placebo and otelixizumab 18 and $27 \mathrm{mg}$ groups,

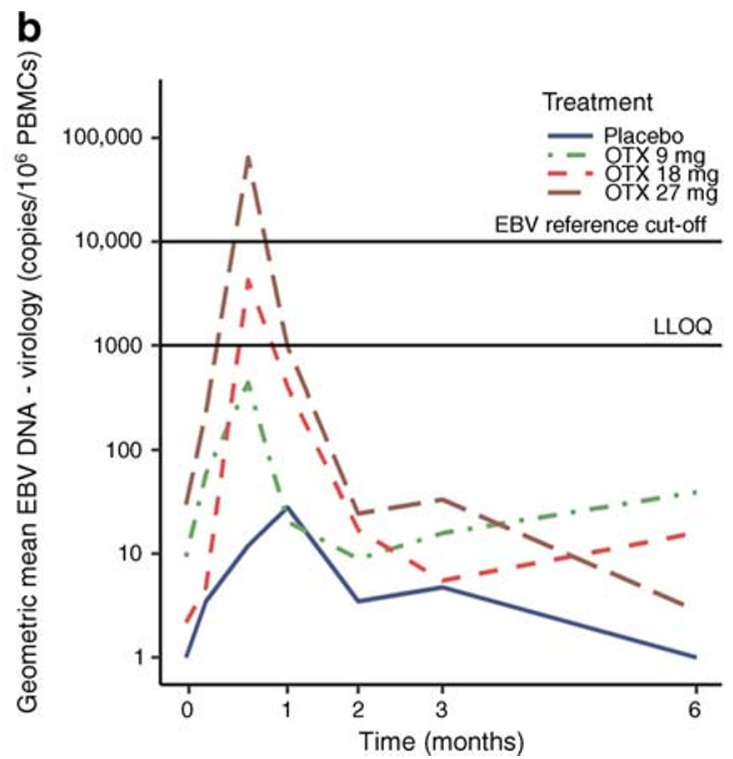

Fig. 2 EBV reactivation showing: (a) proportion of participants with EBV viral load $>10,000$ copies $/ 10^{6}$ PBMCs and proportion with EBV clinical symptoms; and (b) geometric mean copies of EBV viral load per $10^{6}$ PBMCs. LLOQ, lower limit of quantification; OTX, otelixizumab 
Fig. 3 Change from baseline in LS mean ( \pm SEM) of C-peptide weighted mean $\mathrm{AUC}_{0-120}$ min following MMTT. LS: Least squares; OTX, otelixizumab

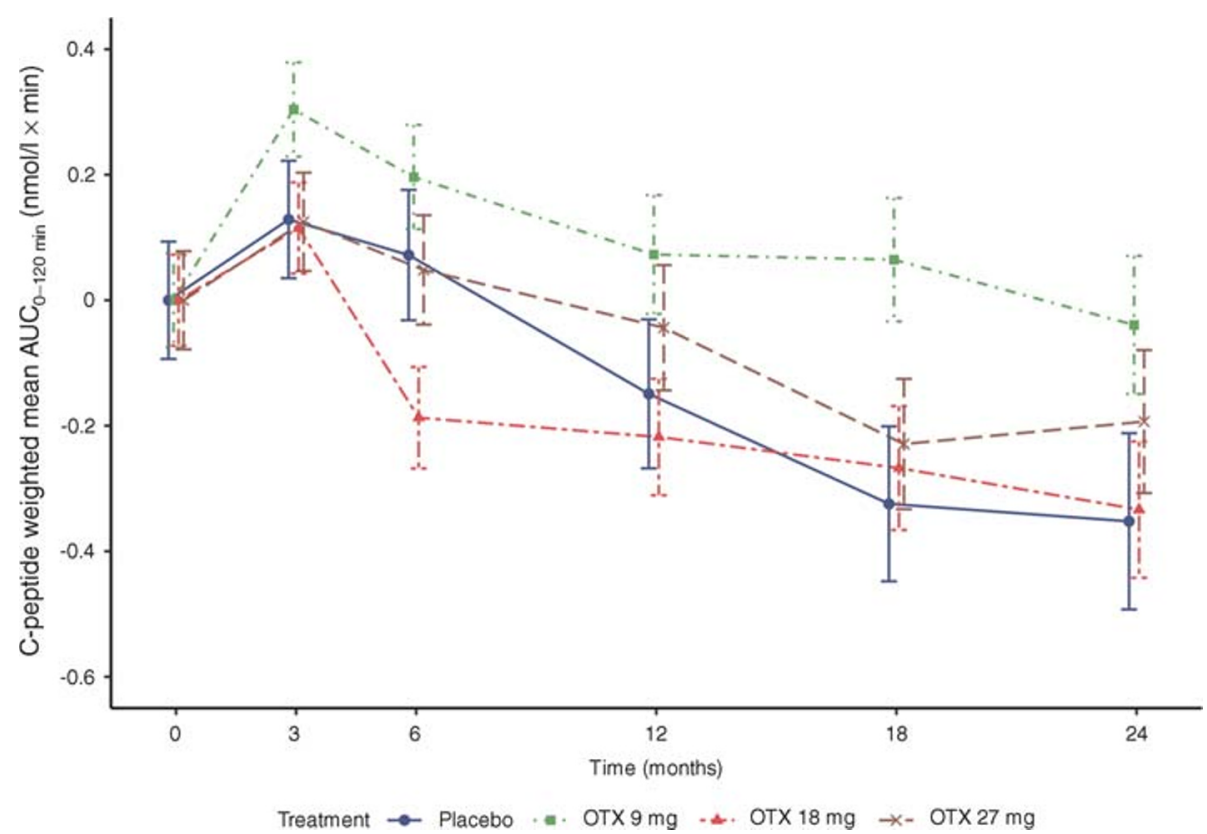

change from baseline in mean AUC glucose was above baseline at all follow-up time points.

Following the hyperglycaemic clamp test, change from baseline in C-peptide and glucose weighted mean $\mathrm{AUC}_{60-140}$ min showed a similar pattern of results to that of MMTT, in that the otelixizumab $9 \mathrm{mg}$ dose showed the best treatment response compared with placebo (ESM Figs 2, 3).

Mean daily insulin use decreased in all groups from baseline to month 3, and then gradually increased over time in all groups with no statistically significant differences observed between the placebo and active-treatment groups. Change from baseline in $\mathrm{HbA}_{1 \mathrm{c}}$ levels (absolute and \%) showed fluctuations over 24 months in all groups, and no marked differences between placebo and active treatment were observed (data not shown).

\section{Immunogenicity}

All recorded participants who received otelixizumab showed positive anti-otelixizumab-binding antibody status at month 3 and remained positive at month 6 . Two participants in the placebo group had positive anti-otelixizumab-binding results predose, which remained positive throughout.

\section{Exploratory biomarkers}

T cell clonal expansion Given that EBV clinical manifestations and elevated levels of EBV viral load were found to be transient, the use of TCR $\beta$ chain immunosequencing to monitor T cell responses following EBV reactivation enabled us, without a technical bias towards known antigens, to determine whether T cells expressing shared TCR $\beta$ chains expanded following EBV reactivation. Changes in productive clonality were consistently observed at all three otelixizumab dose levels; increases peaked at month 1/week 6 (Fig. 4a), in line with EBV viral load values returning to the reference range. At month $1 /$ week 6 , the mean \pm SD change from baseline was $0.010 \pm 0.012,0.041 \pm 0.057,0.063 \pm 0.084$ and $0.318 \pm$ 0.131 for the placebo and otelixizumab 9,18 and $27 \mathrm{mg}$ groups, respectively. The otelixizumab $27 \mathrm{mg}$ group had statistically significant higher clonality compared with placebo at this timepoint $(p=0.009)$; however, neither otelixizumab $9 \mathrm{mg}$ nor $18 \mathrm{mg}$ reached statistical significance vs placebo ( $p=0.075$ and $p=0.28$, respectively). These effects diminished over time; by month 6 , productive clonality returned to baseline levels in participants on otelixizumab $9 \mathrm{mg}$ (mean $\pm \mathrm{SD}$ change from baseline $-0.012 \pm 0.035, p=$ 0.46), whereas levels in the 18 and $27 \mathrm{mg}$ groups were still marginally elevated at month 12 compared with baseline (mean $\pm \mathrm{SD}$ change from baseline $0.024 \pm 0.0185, p=0.02$, and $0.034 \pm 0.029, p=0.06$, respectively). Productive clonality in the placebo group remained relatively stable over time.

As the 'synchronised' kinetics with EBV viral load resolved within 2 months postdose and increased clonality peaked as early as 1 month/6 weeks post treatment, we investigated whether EBV antigens were the likely cause of the T cell expansion, rather than a non-specific agonistic signal delivered by otelixizumab following CD $3 \varepsilon$ target engagement. In a subgroup analysis, we found that participants experiencing EBV reactivation (maximum EBV viral load $>10,000$ copies $/ 10^{6}$ PBMCs) mounted a stronger $\mathrm{T}$ cell response than those without EBV reactivation, as suggested by increased productive clonality (Fig. 4b).

A comparison of TCR $\beta$ chain immunosequencing data queries against a databank holding sequences of EBV- 
Fig. 4 (a) Productive clonality over time by treatment group. (b) Box plot of productive clonality grouped by maximum EBV viral load. Boxes depict the IQR with lines for the 25th percentile, median and 75 th percentile. The whiskers (vertical lines) denote the largest value within $1.5 \times$ IQR above 75 th percentile or below the 25th percentile. Black circles denote individual participant data (a) and individual outliers (b). OTX, otelixizumab a
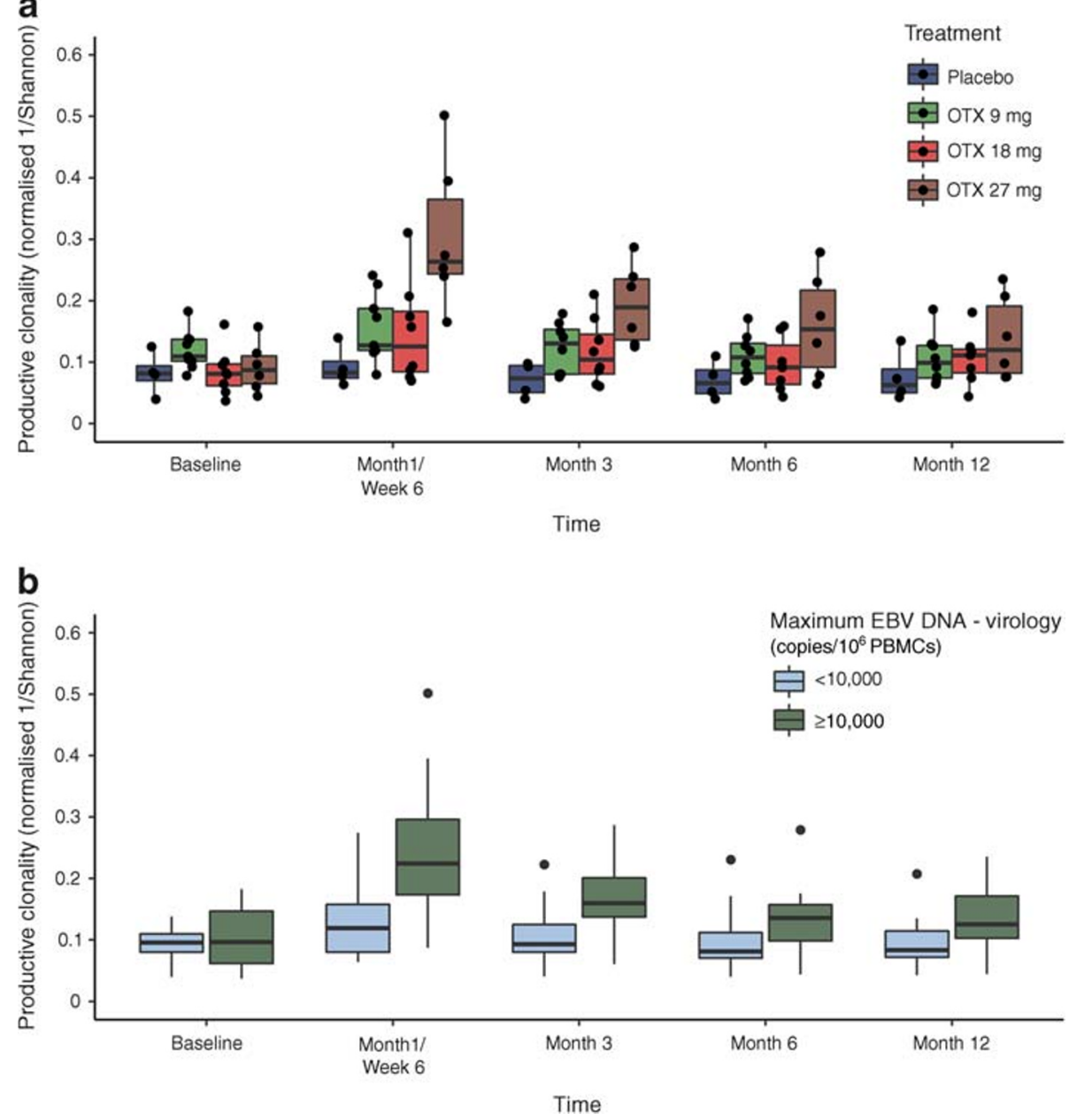

reactive TCR clones from the reported literature, and limited flow cytometry analysis using HLA-A2 restricted multimers
(ESM Fig. 4), provided further evidence that the observed increased clonality is related to $\mathrm{EBV}$-specific $\mathrm{T}$ cell responses.
Fig. 5 Mean \pm SEM partially exhausted $\mathrm{CD}^{+}$memory $\mathrm{T}$ cells over time by metabolic response

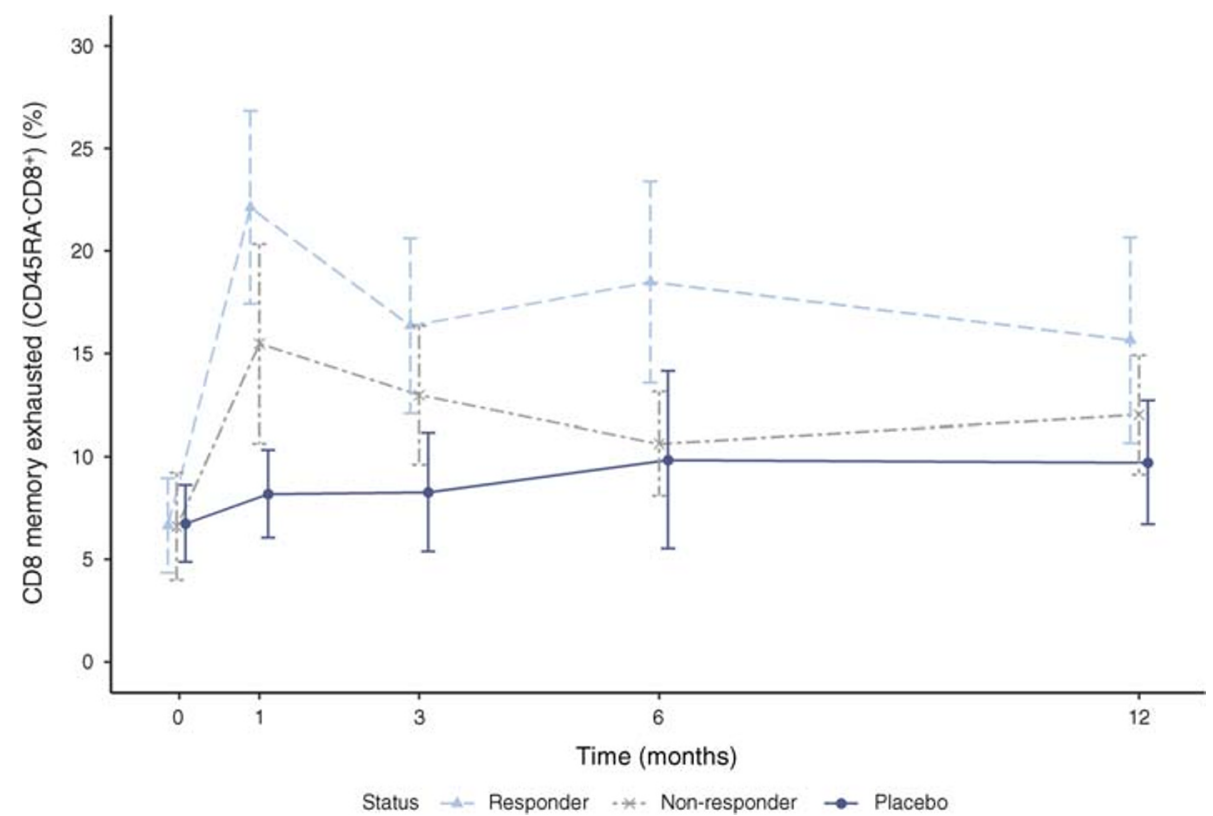


Lymphocyte subsets Except for $\mathrm{CD}^{+} \mathrm{T}$ cells and some subsets thereof, there were no consistent otelixizumabrelated changes from baseline in either the absolute numbers or percentages of any other cell lineages (ESM Table 4). Increases from baseline in partially exhausted memory $\mathrm{CD} 8^{+} \mathrm{T}$ cells, based on a $\mathrm{CD}^{+} \mathrm{CD}^{+} \mathrm{CD} 45 \mathrm{RA}$ Eomes ${ }^{+} \mathrm{KLRG}^{+}{ }^{+} \mathrm{TIGIT}^{+}$phenotype, were consistently observed in all three dose groups as early as month $1 /$ week 6 . Mean \pm SD percentage of partially exhausted $\mathrm{CD}^{+}$memory $\mathrm{T}$ cells increased from $9.5 \pm 10.21 \%$ at baseline to a peak of $28.5 \pm 13.84 \%$ in the otelixizumab $9 \mathrm{mg}$ group, from $6.5 \pm 6.52 \%$ to a peak of $17.0 \pm 16.35 \%$ in the otelixizumab $18 \mathrm{mg}$ group, and from $2.7 \pm 1.65 \%$ to a peak of $16.2 \pm$ $13.23 \%$ in the otelixizumab $27 \mathrm{mg}$ group. Increase from baseline in partially exhausted $\mathrm{CD}^{+}$memory $\mathrm{T}$ cells was more pronounced in participants on otelixizumab who were retrospectively defined as metabolic responders (Fig. 5).

\section{Discussion}

In this Phase I/II study, which was primarily designed to evaluate the safety and tolerability of four cumulative doses of otelixizumab, three cumulative otelixizumab doses $(9,18$ and $27 \mathrm{mg}$ ) were tested and only the 9 and $18 \mathrm{mg}$ doses were well tolerated. The highest planned dose $(36 \mathrm{mg})$ was not given because of predefined protocol stopping criteria on EBV reactivation being met with the $27 \mathrm{mg}$ dose. Following administration of the three doses of otelixizumab, and consistent with findings from previous studies $[9,10,23]$, doserelated CRS AEs and EBV reactivation were reported in this study, despite prophylaxis. During the dosing period, none of the most commonly reported AEs (headache, nausea, vomiting and rash) were above grade 3 toxicity, and nausea and vomiting occurred less frequently in the otelixizumab $9 \mathrm{mg}$ group than in the $18 \mathrm{mg}$ and $27 \mathrm{mg}$ groups, albeit more frequently than with placebo. In comparison, previous studies have reported that 3 weeks after i.v. administration of otelixizumab $48 \mathrm{mg}, 75 \%$ of participants developed a sore throat and $25 \%$, developed fever and cervical adenopathy, both of which were transient and related to EBV reactivation $[9,23]$; these symptoms were not reported after administration of otelixizumab $3.1 \mathrm{mg}[16,17]$.

In our study, EBV reactivation was also dose related; no participants in the otelixizumab $9 \mathrm{mg}$ group had any clinical sign of EBV reactivation, although there was evidence of an increased EBV viral load in some but not all participants in this dosing group. Although EBV reactivation is indicative of a compromised immune system, in agreement with observations made by Keymeulen and colleagues [23], immunocompetence appears to be rapidly restored as evidenced by an expansion of $\mathrm{T}$ cells within 6 weeks postdosing, preceding long-term control over EBV reactivation. In a recent study of individuals at high risk of developing type 1 diabetes, teplizumab at an exposure equivalent to a total cumulative dose of otelixizumab $9 \mathrm{mg}$ resulted in only one participant having EBV-related symptoms (pharyngitis, rhinorrhoea and cough) among eight participants with quantifiable EBV DNA in whole blood at weeks 3 and 6 after dosing [24]. Thus, otelixizumab appears to have a similar profile to teplizumab in terms of EBV reactivation, and possibly a slightly worse profile with respect to CRS symptoms. Given the small number of participants who received the $9 \mathrm{mg}$ otelixizumab dose and limited published safety data on an exposureequivalent teplizumab dose, caution may be warranted in interpreting these findings.

During both the present study and in a previous Belgian Diabetes Registry study [23], no negative long-term effects of treatment were reported, suggesting that EBV reactivation after otelixizumab administration is rather benign and, above all, resolves within a short time frame.

This study, however, has some limitations. First, it was not designed or powered to answer the question of whether doses of otelixizumab from 9 to $36 \mathrm{mg}$ are associated with better or more prolonged maintenance of beta cell function. Second, additional confounding factors have been identified, namely the higher mean baseline beta cell function observed in the otelixizumab $9 \mathrm{mg}$ group and the implementation of a protocol amendment that permitted the additional prophylactic medication ondansetron, a $5 \mathrm{HT}_{3}$-receptor antagonist, in participants receiving otelixizumab $18 \mathrm{mg}$ or more and the effects of which are unknown. Third, this study did not allow us to thoroughly examine the relationship between residual beta cell function and insulin requirements, as recording of insulin use was limited to 7 days before each visit. Finally, good-quality PBMCs for flow analysis were not consistently obtained and multimer analysis was restricted to those who were HLA-A2-positive, thus reducing the number of evaluable participants for immune monitoring.

Previous investigations of an otelixizumab $48 \mathrm{mg}$ cumulative dose demonstrated that preservation of beta cell function depends not only on anti-CD3 therapy, but also on baseline participant characteristics such as younger age, higher baseline beta cell function and the presence of insulin autoantibodies $[9,11,13]$. Recently, teplizumab proved to be efficacious in delaying the onset of overt diabetes in a subgroup of beta cell autoantibody-positive individuals with dysglycaemia [24], providing evidence of the first immune intervention able to delay the diagnosis of diabetes and the requirement for insulin treatment. Our study showed preservation of beta cell function over 18 months in the otelixizumab $9 \mathrm{mg}$ group but not in the 18 and $27 \mathrm{mg}$ groups. The higher mean baseline beta cell function observed in the $9 \mathrm{mg}$ group was not identified as a statistically significant covariate and could be an artefact of sample size, and thus a link between baseline beta cell function and treatment response cannot be ruled out. In this study it was not possible to stratify by baseline beta cell function 
because of the dose-escalation nature of the study design, but this is recommended in future trials in this disease where beta cell function is being assessed and is a primary endpoint.

In this trial, increases from baseline in partially exhausted $\mathrm{CD} 8^{+}$memory $\mathrm{T}$ cells were more pronounced in participants dosed with otelixizumab who were retrospectively defined as metabolic responders. This is consistent with findings described for teplizumab [20]. However, our study established that partially exhausted memory $\mathrm{CD} 8^{+} \mathrm{T}$ cells can expand as early as 1 month after treatment, and this is the earliest time point any study has looked into detailed immunophenotyping. Although the specificity of the partially exhausted $\mathrm{CD} 8^{+}$memory $\mathrm{T}$ cells has thus far not been elucidated, it is likely that both autoreactive and viral-reactive $\mathrm{T}$ cells are contained within this population of $\mathrm{T}$ cells. Herold and colleagues recently hypothesised that following CD3 $\varepsilon$ target engagement by monoclonal antibodies, $T$ cells with high avidity for viral antigens (such as those associated with EBV) may be affected differently to autoreactive $T$ cells with lower avidity [24]. While currently the signatures identified through TCR $\beta$ chain immunosequencing were dominated by EBV reactivation, as the field continues to map specific complementary determining region 3 (CDR3) sequences to their cognate antigens, these data may help to further characterise the $\mathrm{T}$ cells involved in pathogenesis and response to therapy.

In summary, in this dose-finding study, $18 \mathrm{mg}$ was the maximum tolerated dose of otelixizumab and $9 \mathrm{mg}$ was identified as the dose with the better therapeutic index, given the low incidence of transient symptoms related to CRS, the lack of clinical EBV reactivation and early changes in immunophenotyping such as expansion of exhausted memory $\mathrm{CD} 8^{+} \mathrm{T}$ cells, which was more pronounced in participants defined as metabolic responders. These observations might help to clarify the margins of safety and tolerability of antiCD3 monoclonal antibody treatment, both in type 1 diabetes and in delaying the progression to overt type 1 diabetes.

Acknowledgements We acknowledge the participation and the commitment of all participants and their families to this study. We also acknowledge J. Nepom (Benaroya Research Institute, Seattle, WA, USA) for providing details on materials and methods for the flow cytometrybased identification of partial exhausted phenotype, and K. Page (GlaxoSmithKline, Stevenage, UK) for developing and tech transferring the assay to GlaxoSmithKline's Clinical Unit, Cambridge, UK. Editorial support was provided by K. Hollingworth of Continuous Improvement Ltd., Kingsbridge, UK and funded by GlaxoSmithKline. Some of the data were presented as an abstract at the 55th EASD Annual Meeting, 2019.

Data availability Anonymised individual participant data and study documents can be requested for further research from www. ClinicalStudyDataRequest.com.

Funding Funding for this trial was provided by GlaxoSmithKline (NCT02000817). The sponsor/funder was involved in the study design, data collection, interpretation of data and writing of the manuscript. There were no restrictions imposed on authors with respect to submission of this manuscript for publication.
Authors' relationships and activities AvM, DI, JO, NW and AN are GlaxoSmithKline employees and own stocks/shares. RMG is an employee of Adaptive Biotechnologies with salary and stock options. BOR has consulted for Tolerion and ViaCyte and was on a research contract from GlaxoSmithKline for this study. CM serves or has served on advisory panels for Novo Nordisk, Sanofi, Merck Sharp and Dohme, Eli Lilly, Novartis, AstraZeneca, Boehringer Ingelheim, Hanmi Pharmaceuticals, Roche, Medtronic, ActoBio Therapeutics, Pfizer and UCB. Financial compensation for these activities has been received by KU Leuven. KU Leuven has received research support for CM from Medtronic, Novo Nordisk, Sanofi, Merck Sharp and Dohme, Eli Lilly, Roche, Abbott, ActoBio Therapeutics and Novartis. CM serves or has served on speakers bureaux for Novo Nordisk, Sanofi, Merck Sharp and Dohme, Eli Lilly, Boehringer Ingelheim, Astra Zeneca and Novartis. Financial compensation for these activities has been received by KU Leuven. All other authors declare that there are no relationships or activities that might bias, or be perceived to bias, their contribution to this manuscript.

Contribution statement AN, DI and AvM made substantial contributions to conception and design of this study. JO, RM, RMG, BOR, PG, RH, FG and UVdV were involved with data acquisition. AvM, DI and BOR analysed the data. AN, DI, AvM, BK, NW and CM interpreted the data. All of the authors were involved in drafting the manuscript or revising it critically for important intellectual content, and have given final approval of the version to be published. AN is the guarantor of this work.

Open Access This article is licensed under a Creative Commons Attribution 4.0 International License, which permits use, sharing, adaptation, distribution and reproduction in any medium or format, as long as you give appropriate credit to the original author(s) and the source, provide a link to the Creative Commons licence, and indicate if changes were made. The images or other third party material in this article are included in the article's Creative Commons licence, unless indicated otherwise in a credit line to the material. If material is not included in the article's Creative Commons licence and your intended use is not permitted by statutory regulation or exceeds the permitted use, you will need to obtain permission directly from the copyright holder. To view a copy of this licence, visit http://creativecommons.org/licenses/by/4.0/.

\section{References}

1. Atkinson MA, von Herrath M, Powers AC, Clare-Salzler M (2015) Current concepts on the pathogenesis of type 1 diabetesConsiderations for attempts to prevent and reverse the disease. Diabetes Care 38(6):979-988. https://doi.org/10.2337/dc15-0144

2. Paschou SA, Papadopoulou-Marketou N, Chrousos GP, KanakaGantenbein C (2018) On type 1 diabetes mellitus pathogenesis. Endocr Connect 7(1):R38-R46. https://doi.org/10.1530/EC-170347

3. In't Veld P (2011) Insulitis in human type 1 diabetes: The quest for an elusive lesion. Islets 3(4):131-138. https://doi.org/10.4161/isl.3. 4.15728

4. Sherry NA, Tsai EB, Herold KC (2005) Natural history of beta-cell function in type 1 diabetes. Diabetes 54(Suppl 2):S32-S39. https:// doi.org/10.2337/diabetes.54.suppl 2.s32

5. Herold KC, Vignali DA, Cooke A, Bluestone JA (2013) Type 1 diabetes: Translating mechanistic observations into effective clinical outcomes. Nat Rev Immunol 13(4):243-256. https://doi.org/10. 1038/nri3422

6. Nathan DM, for the DCCT/EDIC Research Group (2014) The diabetes control and complications trial/epidemiology of diabetes 
interventions and complications study at 30 years: Overview. Diabetes Care 37(1):9-16. https://doi.org/10.2337/dc13-2148

7. Kalra S, Mukherjee JJ, Venkataraman S et al (2013) Hypoglycemia: The neglected complication. Indian J Endocrinol Metab 17(5):819-834. https://doi.org/10.4103/2230-8210.117219

8. Dayan CM, Korah M, Tatovic D, Bundy BN, Herold KC (2019) Changing the landscape for type 1 diabetes: The first step to prevention. Lancet 394(10205):1286-1296. https://doi.org/10.1016/ S0140-6736(19)32127-0

9. Keymeulen B, Vandemeulebroucke E, Ziegler AG et al (2005) Insulin needs after CD3-antibody therapy in new-onset type 1 diabetes. N Engl J Med 352(25):2598-2608. https://doi.org/10. 1056/NEJMoa043980

10. Herold KC, Hagopian W, Auger JA et al (2002) Anti-CD3 monoclonal antibody in new-onset type 1 diabetes mellitus. N Engl J Med 346(22):1692-1698. https://doi.org/10.1056/NEJMoa012864

11. Keymeulen B, Walter M, Mathieu C et al (2010) Four-year metabolic outcome of a randomised controlled CD3-antibody trial in recent-onset type 1 diabetic patients depends on their age and baseline residual beta cell mass. Diabetologia 53(4):614-623. https:// doi.org/10.1007/s00125-009-1644-9

12. Herold KC, Gitelman SE, Ehlers MR, AbATE Study Team et al (2013) Teplizumab (anti-CD3 mAb) treatment preserves C-peptide responses in patients with new-onset type 1 diabetes in a randomized controlled trial: Metabolic and immunologic features at baseline identify a subgroup of responders. Diabetes 62(11):3766-3774. https://doi.org/10.2337/db13-0345

13. Demeester S, Keymeulen B, Kaufman L et al (2015) Preexisting insulin autoantibodies predict efficacy of otelixizumab in preserving residual $\beta$-cell function in recent-onset type 1 diabetes. Diabetes Care 38(4):644-651. https://doi.org/10.2337/dc14-1575

14. MacDonald A, Ambery P, Donaldson J, Hicks K, Keymeulen B, Parkin J (2016) Subcutaneous administration of otelixizumab is limited by injection site reactions: Results of an exploratory study in type 1 diabetes mellitus patients. Exp Clin Endocrinol Diabetes 124(5):288-293. https://doi.org/10.1055/s-0042-101241

15. Hale G, Rebello P, Al Bakir I et al (2010) Pharmacokinetics and antibody responses to the CD3 antibody otelixizumab used in the treatment of type 1 diabetes. J Clin Pharmacol 50(11):1238-1248. https://doi.org/10.1177/0091270009356299

16. Aronson R, Gottlieb PA, Christiansen JS, DEFEND Investigator Group et al (2014) Low-dose otelixizumab anti-CD3 monoclonal antibody DEFEND-1 study: Results of the randomized phase III study in recent-onset human type 1 diabetes. Diabetes Care 37(10):2746-2754. https://doi.org/10.2337/dc13-0327

17. Ambery P, Donner TW, Biswas N, Donaldson J, Parkin J, Dayan CM (2014) Efficacy and safety of low-dose otelixizumab anti-CD3 monoclonal antibody in preserving $\mathrm{C}$-peptide secretion in adolescent type 1 diabetes: DEFEND-2, a randomized, placebocontrolled, double-blind, multi-Centre study. Diabet Med 31(4): 399-402. https://doi.org/10.1111/dme.12361

18. Vlasakakis G, Napolitano A, Barnard R et al (2019) Target engagement and cellular fate of otelixizumab: A repeat dose escalation study of an anti-CD3 $\varepsilon$ mAb in new-onset type 1 diabetes mellitus patients. Br J Clin Pharmacol 85(4):704-714. https://doi.org/10. 1111/bcp.13842

19. Rosenzweig M, Rosenthal CA, Torres VM, Vaickus L (2010) Development of a quantitative assay to measure EBV viral load in patients with autoimmune type 1 diabetes and healthy subjects. J Virol Methods 164(1-2):111-115. https://doi.org/10.1016/j. jviromet.2009.11.018

20. Long S, Thorpe J, DeBerg HA et al (2016) Partial exhaustion of CD8 T cells and clinical response to teplizumab in new-onset type 1 diabetes. Sci Immunol 1(5):eaai7793. https://doi.org/10.1126/ sciimmunol.aai7793

21. DeFronzo RA, Tobin JD, Andres R (1979) Glucose clamp technique: A method for quantifying insulin secretion and resistance. Am J Phys 237(3):E214-E223. https://doi.org/10.1152/ajpendo. 1979.237.3.E214

22. Gerlo E, Gorus F (1997) Calibration of ion-exchange HPLC measurements of glycohemoglobin: Effect on interassay precision. Clin Chem 43(12):2353-2357. https://doi.org/10.1093/clinchem/ 43.12.2353

23. Keymeulen B, Candon S, Fafi-Kremer S et al (2010) Transient Epstein-Barr virus reactivation in CD3 monoclonal antibodytreated patients. Blood 115(6):1145-1155. https://doi.org/10. 1182/blood-2009-02-204875

24. Herold KC, Bundy BN, Long SA, Type 1 Diabetes TrialNet Study Group et al (2019) An anti-CD3 antibody, teplizumab, in relatives at risk for type 1 diabetes. N Engl J Med 381(7):603-613. https:// doi.org/10.1056/NEJMoa1902226

Publisher's note Springer Nature remains neutral with regard to jurisdictional claims in published maps and institutional affiliations. 